Sasho Kjosev ${ }^{1 *}$, Martin Noveski ${ }^{2}$, Nina Mojsova Kjoseva ${ }^{3}$ ${ }^{1}$ Ss Cyril and Methodius University in Skopje, Faculty of Economics, North Macedonia ${ }^{2}$ Ministry of Finance, Budget and Funds Department, Skopje, North Macedonia ${ }^{3}$ Sparkasse Bank Makedonija AD Skopje, Skopje, North Macedonia

\title{
Public Debt Threshold in the Republic of North Macedonia
}

DOI: 10.7595/management.fon.2021.0018

\begin{abstract}
:
Research question: Is there a non-linear relationship between public debt and economic growth in North Macedonia, in the form of an inverted U-shape? Motivation: Government consumption plays an important role in the stability of the national economy, especially in periods of economic crisis. However, a rapidly growing public debt is a concerning issue nowadays, since it might jeopardize economic growth perspectives. Economic theory suggests that public debt has nonlinear impact on economic growth in the form of an inverted U-shape. In other words, it is believed that after a certain threshold, the public debt will have deleterious impact on economic growth. Idea: Given that such threshold varies significantly across countries, the aim of this paper is to calculate the turning point of the public debt impact in the Republic of North Macedonia. Tools: For this purpose, we use non-linear multiple regression model for the real GDP growth rate as a dependent variable, general government public debt-to-GDP ratio (in nominal and squared terms) as a key independent variable, as well as several other controlling variables. Since theory also suggests reverse causality between economic growth and public debt, we use two different estimation techniques (Ordinary Least Squares and Generalized Method of Moments) to deal with potential endogeneity, and to cross-validate the results. Data: In this regard, we use annual data for the period 1998 -2019, for 14 variables in total, obtained from several different data sources. Findings: Our results show that general government debt in the Republic of North Macedonia positively affects economic growth until it reaches around $30 \%$ of GDP, whereas further indebtedness after that turning point will most likely have a negative impact. Contribution: Given that current debt level is far above the estimated turning point, the need of urgent fiscal consolidation inevitably arises. This is especially important in the light of the ongoing COVID-19 crisis, which imposed the need for strong government intervention and pointed out the importance of the fiscal space for such matter.
\end{abstract}

Keywords: public debt, economic growth, non-linear relationship, threshold, North Macedonia,

JEL classification: C20, E60, H63

\section{Introduction}

In 2007, a financial crisis emerged from the U.S. financial system, namely from the banking sector, with the bankruptcy of Lehman Brothers. As a result, the fiscal imbalances of several countries grew in such a way that they caused a sovereign debt crisis, beginning in Greece and then affecting all Euro-area countries, especially the peripheral countries such as Portugal, Italy, Ireland and Spain (Alfonso \& Alves, 2014). The recent global financial crisis triggered a series of orthodox, unconventional monetary and fiscal policies that led to a sharp increase in the sovereign debt of advanced countries. The massive debt build-up reignited the debate about fiscal sustainability and the impact of the accumulation of government liabilities on financial markets and on real economic performance (Calderon \& Fuentes, 2013).

Government consumption plays an important role in the stability of the national economy, especially in periods of economic crisis (Dudzeviciute, Simelyte \& Liucvaitiene, 2018). However, a rapidly growing public debt is a concerning issue nowadays since it might jeopardize economic growth perspectives (Mencinger, Aristovnik \& Verbic, 2014). Economic theory suggests that public debt has non-linear impact on economic 
growth in a form of inverted U-shape (Ueshina \& Nakamura, 2019; Casares, 2015; Bexheti, Sadiku \& Sadiku, 2020; Liu \& Lyu, 2021; etc.). In other words, it is believed that after a certain threshold, public debt will have a negative impact on economic growth.

A high and growing public debt in North Macedonia is a concerning issue, especially nowadays in light of the COVID-19 pandemics. Expansionary fiscal policy of the government in the past has resulted in several times increase in the public debt since 2008 (in nominal terms), exceeding even the Maastricht criterion of $60 \%$ debt-to-GDP ratio in 2020 . Although expansionary fiscal policy was often justified by boosting economic growth, the real GDP growth rate did not follow the same track. On the contrary, unlike significantly higher growth rates in the pre-crisis period, it remained moderate, at times even negative, barely reaching its highest $3.9 \%$ in 2015 .

Even though the European Commission (2020) foresees economic growth of $4 \%$ in 2021, the upshot of the crisis is still unclear. Garvanlieva - Andonova and Nikolov (2019), also point out the continuous policy of fiscal expansion with optimistic growth scenarios as significant vulnerability for the debt-to-GDP ratios. In this regard, since emerging markets cannot sustain as high debt levels as the advanced economies (Reinhart, Rogoff \& Savastano, 2003), we wonder whether there is a possibility that public debt might also be a factor that endangers economic growth in North Macedonia?! This is especially important in the light of the ongoing COVID-19 crisis, which imposed the need for strong government intervention, and pointed out the importance of the fiscal space for such matter. Namely, as Tashevska, Trpkova-Nestorovska \& Trenovski, (2018) claim, countries should build fiscal buffers and reduce the fiscal burden of debt in good times, in order to be able to react in times of crisis. In this regard, the IMF (2020) explicitly notes that the space for fiscal policy as main countercyclical stabilization tool in North Macedonia is limited. Hence, to help unlocking economy's growth potential and reduce vulnerability to shocks, sound macroeconomic management, along with stronger efforts to improve public debt management, are recommended.

Given the above, this paper investigates the impact of government indebtedness on economic growth in North Macedonia, whereby non-linear (quadratic) relationship is expected. In particular, we aim to estimate the threshold level (turning point) above which general government debt adversely affects economic growth.

\section{Literature Review}

There is currently much cautionary talk in policymaking circles regarding the dangers to the economy's future health posed by crossing a specific threshold in the ratio between government debt and gross domestic product. These fears have been fueled by the report "Growth in a time of debt" (Reinhart and Rogoff, 2010) which argues that: (1) there is no association between debt and growth at low or moderate levels of debt, but that there exists a well-defined threshold (90\%, in their estimation) of government debt relative to gross domestic product (GDP) above which economic growth is hindered; (2) emerging markets face lower thresholds for external debt (public and private) — which is usually denominated in a foreign currency, and (3) there is no apparent contemporaneous link between inflation and public debt levels for the advanced countries as a group.

The relationship between public debt expansion and economic growth has attracted interest in recent years (Gomez-Puig \& Sosvilla-Rivero, 2018a; Ahlborn \& Schweickert, 2018; Abubakar \& Mamman, 2020; etc.), spurred by a sharp increase in government indebtedness in some advanced economies following the global financial crisis (Savoiu, Jasko \& Taicu, 2014). Economists tend to agree that in the short run an increase in public debt arising from fiscal expansion stimulates aggregate demand, which should help the economy grow (Rosoiu, 2019). The longer-term economic impact of public debt accumulation, in contrast, is subject to a more expansive debate, whereby substantial attention has been paid to the examination of economic growth—public debt nexus (Gomez-Puig \& Sosvilla-Rivero, 2017; Bystrov \& Mackiewicz, 2020).

While some empirical studies confirm the adverse impact of government debt on growth (Rahman, Ismail \& Ridzuan, 2019), a growing number of recent works investigate the aforementioned idea of optimal level of government debt and a non-linear, an inverted U-shaped debt-growth relationship. The point here is that there is no single turning point that could be applied to all countries (Bentour, 2018) and a proper investigation is needed into factors that shape the debt impact on growth (Butkus \& Seputiene, 2018).

Alfonso and Alves (2014) analyzed the effect of public debt on economic growth for annual and 5-year average growth rates, as well as the existence of non-linearity effects of debt on growth for 14 European countries from 1970 until 2012. Their results show a negative impact of $-0.01 \%$ for each $1 \%$ increment of public 
debt, and in addition they found average debt ratio thresholds of around 75\%. Gomez-Puig and SosvillaRivero (2018b) analyze the effects of all sources of nonfinancial debt (household, corporate as well as government) accumulation on economic growth in ten euro-area countries during the 1980-2015 period, using three models (a baseline, an asymmetric and a threshold model) based on the empirical growth literature augmented by debt. Their findings suggest that while public debt thresholds are higher in peripheral than in central countries, private debt thresholds are higher in core euro-area countries.

Mencinger et al. (2014) examined and evaluated the direct effect of higher indebtedness on economic growth for countries in the EU which are in the epicenter of the latest sovereign debt crisis. They employ a panel estimation on a generalized economic growth model augmented with a debt variable, while also considering some methodological issues such as the problems of heterogeneity and endogeneity. The calculated debt-to-GDP turning point, where the positive effect of accumulated public debt inverts into a negative effect, is roughly between $80 \%$ and $94 \%$ for the 'old' member states. Yet for the 'new' member states the debtto-GDP turning point is lower, namely between 53\% and 54\%. In their other article, Mencinger et al. (2015) confirmed the general theoretical assumption where at low levels of public debt the impact on growth is positive, whereas beyond a certain debt turning point a negative effect on growth prevails. They calculated that the debt-to-GDP turning point is roughly between $90 \%$ and $94 \%$ for developed economies. Yet, for emerging countries, the debt-to-GDP turning point is lower, namely between $44 \%$ and $45 \%$.

It is interesting to mention the analysis conducted by Bilan and Ihnatov (2015), who analyzed the relationship between public debt and economic growth for a panel of 33 European countries (28 European Union Member States and 5 candidate countries for European membership) over the period 1990-2011. The results confirm the existence of a „U inverted" relationship, with a maximum debt threshold of about $94 \%$ of GDP. After this threshold public debt is expected to negatively affect the economic growth rate, due to higher interest rates, fear of public debt unsustainability and severe budgetary consolidation measures. However, this threshold is found to be more than twice lower in developing European countries compared to the developed ones, as the former enjoy lower credibility, higher vulnerability to shocks and depend more on external capital transfers.

On the other hand, Gashi (2020) examines the impact of public debt in six countries from South-Eastern Europe over the period 2008 to 2017 , by applying three different panel methods: the fixed effects model, the GMM method and the system-GMM method. The results confirm the existence of a „U inverted” relationship, with a maximum debt threshold of about $58 \%$ of GDP. After this threshold, public debt is expected to negatively affect the economic growth rate, due to fear of public debt unsustainability, higher interest rates and severe budgetary consolidation measures.

Most studies of the relationship between public debt and economic growth implicitly assume homogeneous debt effects across their samples. However, starting from a different perspective, Ahlborn and Schweickert (2018) challenge this view and state that there likely is a great deal of cross-country heterogeneity in that relationship. They argue that different degrees of fiscal uncertainty at comparable levels of public debt between three clusters of economic systems (liberal, continental and nordic) constitute a major source of heterogeneity in the debt-growth relationship. Continental countries face more growth reducing public debt effects than especially Liberal countries, while for Nordic countries a non-linear relationship is shown, with negative debt effects kicking in at public debt values of around $60 \%$ of GDP.

As a summary, there are certain points that should be noted:

1) The public debt sustainability is one of the most important concepts nowadays in both developed and transition countries.

2) The existing literature provides arguments on how government borrowing and increasing debt can stimulate, impede, or make no influence on economic development.

3) A growing number of recent research analyses in this field confirms non-linear inverted U-shaped public debt-growth nexus, however estimated public debt threshold level (or turning point) above which relationship turns from positive to negative, varies sharply across studies. This raises the need to analyze key factors that might determine this debt threshold.

4) Despite extensive research which has already been undertaken, the issue as to whether there is a debt-threshold effect continues to be strongly debated. Nevertheless, the choice of debt-threshold determinants is arbitrary. Hence, it is imperative that a theory be developed that may lead us toward a more systematic approach to the choice.

5) Although the effect of debt is undesirable, governments have to trade-off the incremental debt to stimulate aggregate demand and consequently growth. Debt would not be the main point on the political and academic agenda if each economy possessed sufficient and structural mechanisms to deal with it (to concentrate on how efficiently each economy could improve its economic path). 
6) As a result, the identified public debt thresholds should not be appreciated as absolute landmarks for judgments but interpreted with caution. Depending on the particularities of each country and the time period, but especially on the destination given to borrowed resources, the adverse effects may occur at even lower public debt ratios, while the contrary is also not to be excluded.

\section{Data and Methodology}

Following commonly employed methodological approach (Checherita \& Rother, 2010; Mencinger et al., 2014; Bilan \& Ihnatov, 2015; etc.), we investigate the relationship between public debt and economic growth in North Macedonia using the augmented growth model. Essentially, it is a multiple regression model in which economic growth is a function of several factors, such as: labour and human capital, accumulation of physical capital, openness of the economy and external competitiveness, as well as the fiscal and monetary policy mix of the country. In addition, public debt variable is also included in the model, whereby nonlinear relationship with the dependent variable is assumed.

For the purposes of our analysis, we use annual data for the period 1998 - 2019. The selection of independent variables is based on the empirical literature, whereas data are cross-checked among several different data sources, such as the data bases of the National Bank and the Ministry of Finance of North Macedonia, AMECO database, and World development indicators database. This is especially important since this is the way to ensure consistency and reliability of the data, supported by credible institutions.

Mathematically, the theoretical model can be written as follows:

$$
G D P_{g}=\beta_{0}+\beta_{1} D E B T+\beta_{2} D E B T^{2}+\beta_{3 . i} X_{i}+u
$$

where:

- $G D P_{g}$ is Real GDP growth rate (\%),

- $D E B T$ is General government debt (\% of GDP),

- $X_{i}$ is vector of controlling variables, including real interest rates, monetary base M1 (annual change, $\%$ ), net exports (\% of GDP), exchange rate MKD/USD (average) and a dummy variable to capture unexplained shocks in 2011 and 2012,

- $\boldsymbol{u}$ is the error term.

Based on the literature review, a non-linear relationship in the form of inverted U-shape exists if both $\beta_{1}$ and $\beta_{2}$ coefficients are statistically significant, whereby $\beta_{1}$ is positive and $\beta_{2}$ is negative. This means that beyond a certain turning point public debt will have deleterious impact on economic growth. In this regard, the turning point (TP), as extremum value, is estimated using the following equation proposed by Lind and Mehlum (2007):

$$
T P=-\frac{\hat{\beta}_{1}}{2 \hat{\beta}_{2}}
$$

However, since TP is calculated as a ratio of the estimated parameters, where the denominator $\hat{\beta}_{2}$ can take values close to zero, it is likely that the moments of TP are undefined, as in the case of the Cauchy distribution. In such case, theoretical literature provides several alternative methods for calculation of the confidence intervals for the extremum value. In particular, we employ two most widely used methods, the Delta method and the Fieller method, as suggested in Hirschberg and Lye (2005). The Delta method concerns the approximate probability distribution for a function of an asymptotically normal statistical estimator, limiting the variance of that estimator. On the other hand, the Fieller method is an analytical method for calculating the confidence interval of two ratios, where each part of the ratio may be from a different distribution. The two methods, as specified in equations 3 and 4 , are used conjointly in order to cross-validate the results.

Delta method

$$
C I=T P \mp t_{\alpha / 2} \sqrt{\frac{\hat{\sigma}_{1}^{2} \hat{\beta}_{2}^{2}-2 \hat{\beta}_{1} \hat{\beta}_{2} \hat{\sigma}_{12}+\hat{\beta}_{1}^{2} \hat{\sigma}_{2}^{2}}{4 \hat{\beta}_{2}^{4}}}
$$

Fieller method

$$
C I=\frac{t_{\alpha / 2}^{2} \hat{\sigma}_{12}-\hat{\beta}_{1} \hat{\beta}_{2} \mp \sqrt{\left(\hat{\beta}_{1} \hat{\beta}_{2}-t_{\alpha / 2}^{2} \hat{\sigma}_{12}\right)^{2}-\hat{\sigma}_{1}^{2} \hat{\sigma}_{2}^{2}\left(\hat{t}_{2}^{2}-t_{\alpha / 2}^{2}\right)\left(\hat{t}_{1}^{2}-t_{\alpha / 2}^{2}\right)}}{2 \hat{\sigma}_{2}^{2}\left(\hat{t}_{2}^{2}-t_{\alpha / 2}^{2}\right)}
$$


where:
$t_{\alpha / 2}$ is critical value for $n-k$ degrees of freedom;
$\hat{\sigma}_{1}^{2}$ and $\hat{\sigma}_{2}^{2}$ are variances of $\hat{\beta}_{1}$ and $\hat{\beta}_{2}$ respectively;
$\hat{\sigma}_{12}$ is covariance of $\hat{\beta}_{1}$ and $\hat{\beta}_{2}$;
$\hat{t}_{1}^{2}$ and $\hat{t}_{2}^{2}$ are $\mathrm{t}-$ statistics of $\hat{\beta}_{1}$ and $\hat{\beta}_{2}$ respectively.

Regarding the model estimation, we primarily base our findings on the Ordinary Least Squares (OLS) method, although we also use Generalized Method of Moments (GMM) to validate the results. The procedure follows deductive logic, given the limited and relatively small sample (22 observations). Namely, using too many independent variables in case of small sample size might significantly reduce the degrees of freedom, thus jeopardizing the reliability of the obtained estimates. Therefore, we start with an unrestricted empirical model, whereby gradually exclude statistically insignificant variables, until we end up with compact and reliable model (equation 1). This technique is also beneficial in terms of checking the robustness of the obtained coefficients since they are estimated using different model specifications.

Special attention in the model estimation procedure is paid to the assumptions of the classical linear regression model (CLRM). Firstly, all variables are subjected to unit root tests, in order to determine the order of integration of each variable. In order to prevent spurious results caused by using non-stationary variables in the regression, we use first differences of the non-stationary variables in the models (except for the public debt). Secondly, we check the correlation coefficients and variance-inflation factors so as to prevent multicollinearity, as well as to eliminate variables that are uncorrelated, and/or highly correlated with the dependent variable. In this regard, unlike many empirical papers, we do not include real GDP per capita as a proxy for economic development of the country in our model, since it is integrated of order 1 , and its first difference is almost perfectly correlated with the dependent variable. Thirdly, we check the assumptions for normal distribution, homoscedasticity and absence of serial correlation in the model residuals. In this regard, in order to prevent any consequences of possible heteroskedasticity in the models, we use robust standard errors. Finally, since the economic theory suggests possible reverse causality between economic growth and public debt (endogeneity), we re-estimate the model using Generalized Method of Moments, whereby as instruments we use GDPg and DEBT variables with one lag, initially specified controlling variables under $X$ in equation one, as well as several other growth-related variables according to the empirical literature. Baum et al. (2002) suggest that if heteroskedasticity is present, GMM is preferable since estimators would have better efficiency than a simple IV estimators. However, GMM can have poor small sample properties. Therefore, to ensure reliability of our findings, we estimate the models using both estimation methods, and calculate TPs accordingly.

\section{Limitations}

Regardless of the strict methodology we follow, there are several limiting factors that we need to beware of. Firstly, it is the data quality and consistency. Namely, in spite of the general guidelines on wider scoping of the public debt (Dippelsman, Dziobek, \& Gutierrez Mangas, 2012), there are numerous examples of methodological inconsistencies for their calculation across countries, as well as misinterpretations of the term public debt. Consequently, there are many empirical papers with incomparable findings, due to the different data they rely on, mostly referring to different levels of the government. In order to expand our data sample to maximum extent, we use data on general government debt, instead of public debt, meaning that we do not account for the public enterprises' guaranteed and non-guaranteed debt.

Another limiting factor might be the methodological approach itself. For example, empirical literature also suggests other econometric techniques for estimation of the public debt threshold level, mostly using dummy variables (Hansen, 1999; Wang, 2015; etc.). However, we believe that this approach is not always suitable, especially for small samples, and/or if there is an indication that the threshold has not yet been reached, or it is too close to the data range. Also, unlike many studies that address this issue using panel data for a group of countries, we aim to make use of the country-specific conditions for a single country, North Macedonia in particular. We believe that heterogeneity between countries, even from the same geographical region, might be a source of significant disparities (Ahlborn \& Schweickert, 2018), imposing a need for generalization.

Finally, from time perspective, our analysis only focuses on the short run implications of the public debt, leaving long run macroeconomic impact for further research. 


\section{Empiricl Results}

Following the above methodology, our results unanimously confirm the initial assumption that public debt in North Macedonia has non-linear impact on economic growth in a form of inverted U-shape. Model parameters $\hat{\beta}_{1}$ and $\hat{\beta}_{2}$, estimated as specified in equation 1 , are both statistically significant and have proper signs $\left(\hat{\beta}_{1}>0\right.$ and $\left.\hat{\beta}_{2}<0\right)$, which is sufficient evidence in favor of this claim.

In line with the previously established methodology, the theoretical model in equation 1 is estimated under several different model specifications, whereby highly correlated and statistically insignificant controlling variables are excluded. The final estimated model expresses the real GDP growth rate in North Macedonia as a function of the public debt (in nominal and squared terms), real interest rates, monetary base, real exchange rate and net export. This model estimated using OLS and GMM methods, whereby the results are consistent and unanimous (Table 1).

Furthermore, estimated models are statistically significant and well-fitted, explaining approximately $90 \%$ of the variations in the dependent variable. Diagnostic tests confirm that model residuals are normally distributed, with constant variance (homoscedastic) and serially uncorrelated.

Additionally, Sargan-Hansen J-statistics in the GMM estimate is low (6.64), which confirms the joint validity of the over-identifying restrictions even at 0.01 significance level, meaning that instruments are consistent (Roodman, 2009). However, the endogeneity test fails to reject the null hypothesis that DEBT and DEBT ^ 2 variables are exogenous (low difference in J-statistics), thus suggesting that maybe OLS estimation is a better choice. In any case, the obtained results are unanimous, so the estimation method (OLS or GMM) seems irrelevant.

Table 1: Estimated coefficients (final model)

\begin{tabular}{|c|c|c|}
\hline Independent variables & OLS & GMM \\
\hline C & -14.55 * & -14.84 * \\
\hline DEBT & 1.223 * & 1.232 * \\
\hline $\mathrm{DEBT}^{\wedge} 2$ & -0.0207 * & -0.02072 * \\
\hline $\mathrm{D}(\mathrm{RIR})$ & -0.376 * & $-0.3714^{*}$ \\
\hline M1 & 0.0814 * & 0.0833 * \\
\hline $\mathrm{D}$ (NETEX) & -0.349 * & $-0.357^{*}$ \\
\hline Independent variables & OLS & GMM \\
\hline $\mathrm{C}$ & -14.55 * & -14.84 * \\
\hline DEBT & 1.223 * & 1.232 * \\
\hline $\mathrm{DEBT}^{\wedge} 2$ & -0.0207 * & -0.02072 * \\
\hline $\mathrm{D}(\mathrm{RIR})$ & -0.376 * & -0.3714 * \\
\hline M1 & 0.0814 * & 0.0833 * \\
\hline $\mathrm{D}$ (NETEX) & $-0.349 *$ & $-0.357 *$ \\
\hline $\mathrm{D}(\mathrm{EXCH})$ & 0.068 ** & 0.0673 ** \\
\hline DUM & -3.632 * & $-3.677^{\star}$ \\
\hline Turning Point & 29.5 & 29.7 \\
\hline 95\% Cl (Fieller) & 28.3-30.4 & $29.0-30.4$ \\
\hline 95\% Cl (Delta) & $28.5-30.5$ & $29.1-30.4$ \\
\hline Adj. R-sq. & 0.8815 & 0.8798 \\
\hline Jarque-Bera test & 1.13 & 1.23 \\
\hline Durbin-Watson & 2.25 & 2.17 \\
\hline Serial correl. LM Test (1 lag) & 1.17 & \\
\hline White test (no cross terms) & 10.79 & \\
\hline Reset test & 2.63 & \\
\hline F-stat. & 23.33 * & \\
\hline J-statistics & & 6.64 \\
\hline Endogeneity test diff. in J-stat. & & 0.36 \\
\hline
\end{tabular}




\begin{tabular}{|c|c|c|}
\hline Independent variables & OLS & GMM \\
\hline \multicolumn{3}{|c|}{$\begin{array}{l}\text { Note: }{ }^{*},{ }^{\star *} \text { and }{ }^{\star \star \star *} \text { represent statistical significance at } 0.01 \text {, } \\
0.05 \text { and } 0.1 \text { respectively }\end{array}$} \\
\hline $\mathrm{D}(\mathrm{EXCH})$ & $0.068 * \star$ & $0.0673 * *$ \\
\hline DUM & -3.632 * & $-3.677^{*}$ \\
\hline Turning Point & 29.5 & 29.7 \\
\hline 95\% Cl (Fieller) & $28.3-30.4$ & $29.0-30.4$ \\
\hline 95\% Cl (Delta) & $28.5-30.5$ & 29.1-30.4 \\
\hline Adj. R-sq. & 0.8815 & 0.8798 \\
\hline Jarque-Bera test & 1.13 & 1.23 \\
\hline Durbin-Watson & 2.25 & 2.17 \\
\hline Serial correl. LM Test (1 lag) & 1.17 & \\
\hline White test (no cross terms) & 10.79 & \\
\hline Reset test & 2.63 & \\
\hline F-stat. & 23.33 * & \\
\hline J-statistics & & 6.64 \\
\hline Endogeneity test diff. in J-stat. & & 0.36 \\
\hline
\end{tabular}

Based on the estimated model, we calculate a turning point of around $30 \%$ of GDP, above which a further increase in the public debt would negatively affect the economic growth. Furthermore, we calculate $95 \%$ confidence intervals using Fieller and Delta methods as specified in equations 3 and 4 . Calculated turning points based on the OLS and GMM estimates of the model, along with their 95\% confidence intervals, are shown in Figure 1. Although OLS suggests slightly wider confidence intervals for $(28.3-30.4)$, it is a relatively narrow interval which lies within the data range for the general government public debt (between 20.5 and 45.6).

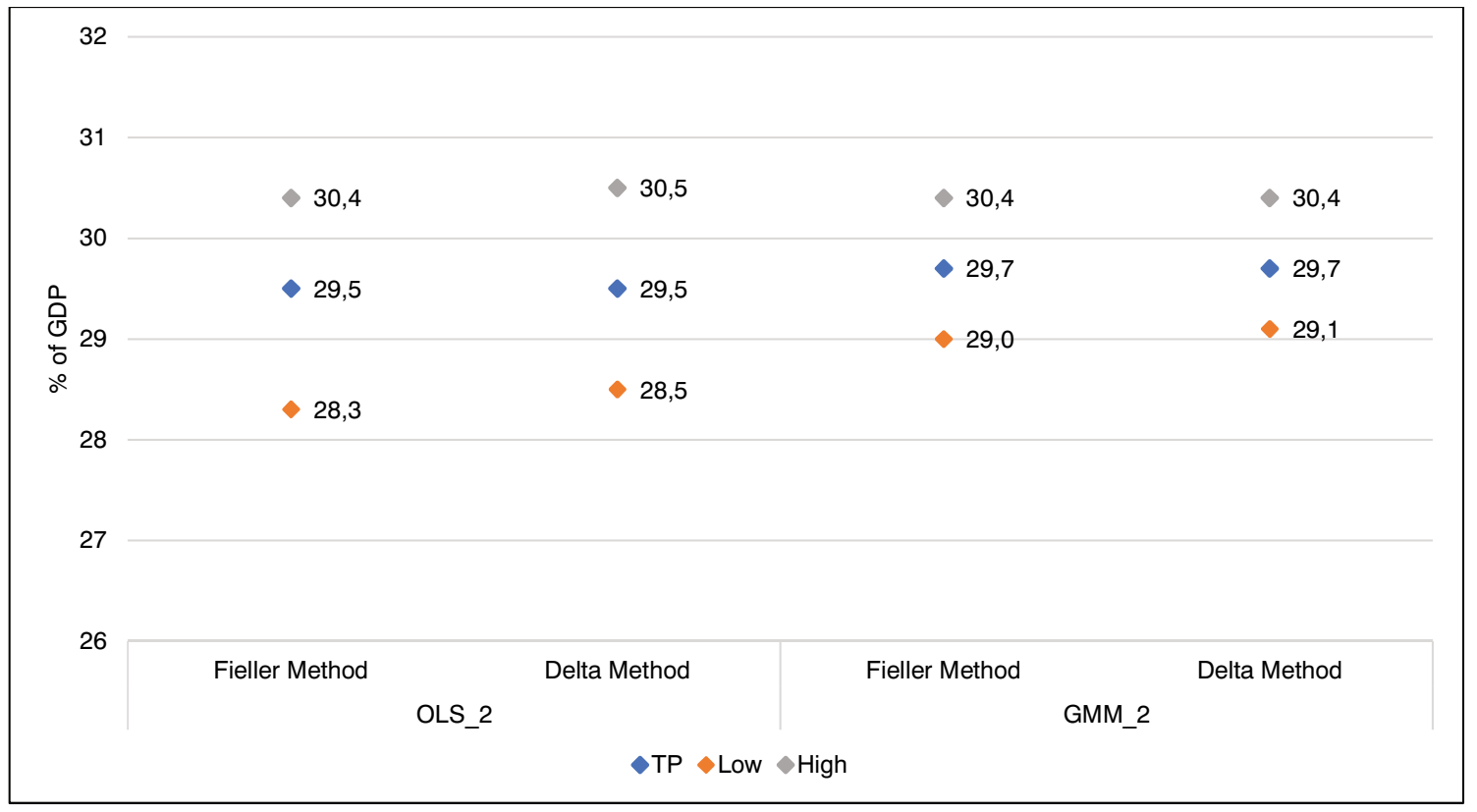

Figure 1: Calculated TPs and their 95\% confidence intervals

Although with much higher threshold (od around 58\% of GDP), non-linear relationship between public debt and economic growth in North Macedonia is also confirmed by Gashi (2020) and Fetai et al. (2020). However, given the overall macroeconomic situation in the country, it is hard to believe that Macedonian econ- 
omy could sustainably bear such a high burden of public debt, without jeopardizing economic growth perspectives. As literature suggests, threshold levels of around $60 \%$ are typical for many advanced economies, Nordic countries for example (Ahlborn \& Schweickert, 2018). On the other hand, emerging economies face lower thresholds, around 45\% (Mencinger et al., 2015).

Having in mind that general government debt is used in this analysis, instead of public debt (which is usually about 10 percentage points lower), a threshold level of $30 \%$ debt-to-GDP ratio seems reasonable and fully compatible with the majority of the empirical literature.

\section{Conclusion}

The question whether public debt is a means of or a burden on economic growth is widely discussed in the scientific literature. The theory provides arguments on how government borrowing and increasing debt can stimulate, impede or make no influence on economic development. There is quite a lot of empirical research devoted to the analysis of the impact the public debt makes on economic growth; despite this, the results are ambiguous. The growing volume of recent research in this field confirms non-linear inverted U-shaped public debt-growth nexus, however estimated public debt threshold level (or turning point) above which relationship turns from positive to negative varies sharply across studies (Butkus \& Seputiene, 2018).

Following this idea, our objective was to examine whether such relationship exists in the case of North Macedonia, and if it does, to calculate the corresponding turning point. For this purpose, we use a multiple regression model for the period 1998 - 2019, having GDP growth rate as dependent variable, and general government debt-to-GDP ratio (in nominal and squared terms) as independent variables. Our model also includes other controlling factors, as suggested in the economic growth literature, such as: labour and human capital, accumulation of physical capital, openness of the economy and external competitiveness, as well as the fiscal and monetary policy mix of the country. To ensure robustness and reliability of the results, the theoretical model is estimated under several different model specifications, using OLS and GMM methods. The results undoubtedly go in favor of the hypothesis that public debt affects economic growth non-linearly in the form of an inverted U-shape, whereby we calculate the turning point for the case of North Macedonia at around 30\% of GDP. We also provide estimates for the $95 \%$ confidence intervals of this turning point, using Fieller and Delta methods. Namely, OLS estimates suggest confidence intervals ranging from around 28.5 to $30.5 \%$ of GDP, whereas GMM estimates are even more precise, going from 29 to $30.4 \%$ of GDP.

Given that current debt level is far above the estimated turning point, the need for urgent fiscal consolidation inevitably arises (Tashevska \& Trenovski, 2017). However, even though general government debt level of 30\% of GDP (as calculated) would significantly reduce the debt sustainability pressure in North Macedonia, while promoting growth at the same time, it should not be mistaken as optimal level of indebtedness. Namely, as IMF suggests, to ensure resilience to shocks (such as the ongoing COVID-19 crisis) without jeopardizing economic growth perspectives we need sufficient fiscal buffer to mitigate their impact. Therefore, the optimal debt level for North Macedonia would be somewhere below this point, depending on the fiscal capacity of the country.

This research, however, has its own limitations as well. Namely, the analysis essentially focuses on the short run implications of the public debt on economic growth in North Macedonia. Consequently, the employed empirical model does not contain any dynamics in it. That being the case, we believe that this research is a solid ground for further analysis of the long run macroeconomic impact of the public debt in North Macedonia.

\section{Acknowledgements}

Some parts of this paper have been presented at the 1st International Scientific Conference on "Economic and Business Trends Shaping the Future - EBTSF", held November 12-13, 2020 in Skopje, N. Macedonia.

\section{REFERENCES}

[1] Abubakar, A. B., \& Mamman, S. O. (2020). Permanent and transitory effect of public debt on economic growth. Journal of Economic Studies.

[2] Ahlborn, M. \& Schweickert, R. (2018). Public debt and economic growth-Economic systems matter. International Economics and Economic Policy, 15(2), 373-403. DOI: 10.1007/s10368-017-0396-0.

[3] Alfonso, A., \& Alves, J. (2014). The Role of Government Debt in Economic Growth. WP16/2014/DE/UECE, Department of Economics, Lisboa School of Economics and Management.

[4] Baum, C.F., Schaffer, M.E., \& Stillman, S. (2002). Instrumental variables and GMM: Estimation and testing. Boston College Economics Working Paper 545, 02 November.

[5] Bentour, El Mostafa. (2018). On the public debt and growth threshold: One size does not necessarily fit all. Cahier de recherche du Creg, $n^{\circ} 2018.01$. 
[6] Bexheti, A., Sadiku, L., \& Sadiku, M. (2020). The Impact of Public Debt on Economic Growth: Empirical Analyses for Western Balkan Countries. In Economic and Financial Challenges for Balkan and Eastern European Countries (pp. 13-32). Springer, Cham.

[7] Bilan, I. \& Ihnatov, I. (2015). Public Debt and Economic Growth: A Two-Sided Story. International Journal of Economic Sciences, 4(2), 24-39. DOI: 10.20472/ES.2015.4.2.003.

[8] Butkus, M. \& Seputiene, J. (2018). Growth Effect of Public Debt: The Role of Government Effectiveness and Trade Balance. Economies, 6(4), 62. .

[9] Bystrov, V., \& Mackiewicz, M. (2020). Recurrent explosive public debts and the long-run fiscal sustainability. Journal of Policy Modeling, 42, 437-450.

[10] Calderon, C., \& Fuentes, J.R. (2013). Government Debt and Economic Growth. IDB Working Paper series IDB-WP-424, Inter-American Development Bank.

[11] Casares, E. R. (2015). A relationship between external public debt and economic growth. Estudios Económicos (México, DF), 30(2), 219-243.

[12] Checherita, C., \& Rother, P. (2010). The Impact of High and Growing Government Debt on Economic Growth: An Empirical Investigation for the Euro Area. Working Paper No. 1237, European Central Bank.

[13] Dippelsman, R., Dziobek, C., \& Gutierrez Mangas, C.A. (2012). What Lies Beneath: The Statistical Definition of Public Sector Debt, an Overview of the Coverage of Public Sector Debt for 61 Countries. IMF Staff Discussion Note, International Monetary Fund, 27 July.

[14] Dudzeviciute, G., Simelyte, A., \& Liucvaitiene, A. (2018). Government expenditure and economic growth in the European Union countries. International Journal of Social Economics, 45(2), 372-386. .

[15] European Commission (2020). European Economic Forecast: Spring 2020. European Economy Institutional Paper 125, European Commission. DOI:10.2765/788367 (online), [Accessed: 01.06.2020].

[16] Fetai, B., Avdimetaj, K., Bexheti, A., \& Malaj, A. (2020). Threshold effect of public debt on economic growth: An empirical analysis in the European transition countries. Zbornik radova Ekonomskog fakultata u Rijeci. 38(2), 381-406.

[17] Garvanlieva - Andonova, V., \& Nikolov, M. (2019). Political economy of public debt \& debt sustainability: The case of Macedonia, Implementing the IMF's debt sustainability analysis tool for market access countries to Macedonia. Center for economic analyses - CEA, Skopje.

[18] Gashi, B. (2020). The Impact of Public Debt on the Economic Growth in South Eastern Europe: An Empirical Panel Investigation. Economic Studies (Ikonomicheski Izsledvania), 29(2), 3-18.

[19] Gomez-Puig, M., \& Sosvilla-Rivero, R. (2017). Public debt and economic growth: Further evidence for the euro area. Research Institute of Applied Economics. Working Paper 2017/15, 1-41.

[20] Gomez-Puig, M., \& Sosvilla-Rivero, S. (2018a). Public debt and economic growth: Further evidence for the Euro area. Acta Oeconomica, 68(2), 209-229. DOI: 10.1556/032.2018.68.2.2.

[21] Gomez-Puig, M., \& Sosvilla-Rivero, S. (2018b). Nonfinancial debt and economic growth in euro-area countries. Journal of International Financial Markets, Institutions \& Money, 56, 17-37. DOI: 10.1016/j.intfin.2018.03.005.

[22] Hansen, B. (1999). Threshold effects in non-dynamic panels: Estimation, testing, and inference. Journal of Econometrics, 93, 345-368. DOI:10.1016/S0304-4076(99)00025-1.

[23] Hirschberg, J.G., \& Lye, J.N. (2005). Inferences for the extremum of quadratic regression models. Research paper number 906. Department of Economics - University of MelbournelMF (2020). Executive Board Concludes 2019 Article IV Consultation with the Republic of North Macedonia. IMF Country Report No. 20/24, 27 January.

[24] Lind, J.T., \& Mehlum, H. (2007). With or Without U? - The appropriate test for a U-shaped relationship. Oxford Bulletin of Economics and Statistics, 72(1), 109-118.

[25] Liu, Z. \& Lyu, J. (2021) Public debt and economic growth: threshold effect and its influence factors, Applied Economics Letters, 28:3, 208-212, DOI:

[26] Mencinger, J., Aristovnik, A., \& Verbic, M. (2014). The impact of growing public debt on economic growth in the European Union. Amfiteatru Economic Journal, 16(35), 403-414.

[27] Mencinger, J., Aristovnik, A., \& Verbic, M. (2015). Revisiting the Role of Public Debt in Economic Growth: The Case of OECD Countries. Engineering Economics, 26(1), 61-66. DOI: 10.5755/j01.ee.26.1.4551.

[28] Rahman, N. H. A., Ismail, S., \& Ridzuan, A. R. (2019). How does public debt affect economic growth? A systematic review. Cogent Business \& Management, 6(1), 1701339. DOI: 10.1080/23311975.2019.1701339.

[29] Reinhart, C., \& Rogoff, K. (2010). Growth in a Time of Debt. NBER Working Paper No. 15639.

[30] Reinhart, C., Rogoff, K., \& Savastano, M. (2003). Debt Intolerance. Brookings Papers on Economic Activity, 1, 1-74.

[31] Roodman, D. (2009). How to do xtabond2: An introduction to difference and system GMM in Stata. The Stata Journal, 9(1), 86-136.

[32] Rosoiu, I. (2019). The Impact of Public Debt on Economic Growth: Case Study. Cross-Cultural Management Journal, 21(1), 73-78.

[33] Savoiu, G., Jasko, O., \& Taicu, M. (2014). The Evolution of the Public Debt in Romania and Serbia, During and After the Global Recession. Management: Journal of Sustainable Business and Management Solutions in Emerging Economies, 19(72), 5. DOI: 10.7595/management.fon.2014.0021. 
[34] Tashevska, B., \& Trenovski, B. (2017). Testing fiscal sustainability in the Republic of Macedonia - a VAR approach. 26th International Scientific Conference on Economic and Social Development - "Building Resilient Society" - Zagreb, Croatia, 8-9 December 2017.

[35] Tashevska, B., Trpkova-Nestorovska, M., \& Trenovski, B. (2018). Estimating a fiscal reaction function for the South East European countries. Proceedings of the ISCCRO'18: The 2nd International Statistical Conference in Croatia, Opatija, Croatia, 10-11 May 2018, "New Advances in Statistical Methods Applications for a Better World“.

[36] Ueshina, M., \& Nakamura, T. (2019). An Inverted U-Shaped Relationship between Public Debt and Economic Growth under the Golden Rule of Public Finance. Theoretical Economics Letters, 9(06), 1792 . .

[37] Wang, Q. (2015). Fixed-effect panel threshold model using Stata. The Stata Journal, 15(1), 121-134. DOI:10.1177/1536867X1501500108.

Received: 2021-01-27

Revisions requested: 2021-03-07

Revised: 2021-03-24 (2 revisions)

Accepted: 2021-03-25

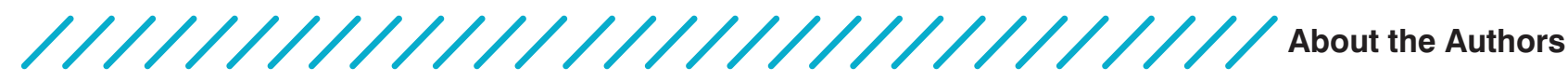

$\begin{array}{r}\text { Sasho Kjosev } \\ \text { Ss. Cyril and Methodius University in Skopje, Faculty of Economics-Skopje, North Macedonia } \\ \text { skosev@eccf.ukim.edu.mk }\end{array}$

Sasho Kjosev is a Full Professor with a PhD in development economics. For more than twenty-two years he has been employed at the Department of Economics at the Faculty of Economics. He is also President of the Association for regional development BALKAN

ECONOMIC FORUM. Sasho's areas of expertise are macroeconomic planning,

development planning techniques, national accounts, sustainable development, labour economics, economics of innovation and agricultural policy. He participated in more than 30 EU, UNDP and World Bank funded projects in the country, including the preparation of the National Development Strategy and National Sustainable

Development Strategy for Macedonia. He authored 7 books and more than 60 articles published in domestic and international journals and conference proceedings.

Martin Noveski

Ministry of Finance, Budget and Funds Department, Skopje, North Macedonia martin.noveski@finance.gov.mk

Martin Noveski is a budget analyst in the Ministry of Finance of the Republic of North

Macedonia with 10 years of professional experience. Also, he is President of the

Association of economists, statisticians and econometricians SIGMA STAT Skopje.

Martin holds a master's degree in Statistical Method for Business and Economy,

specifically in advanced econometrics. In the course of his career Martin has been involved in the implementation of several projects, domestically and abroad, and has participated in many training programs, including the 'EU Scheme for Young

Professionals in the Western Balkans', financed by the European Commission.

His fields of expertise are macroeconomic growth and development, fiscal policy and public finance management.

Nina Mojsova Kjoseva Sparkasse Bank Makedonija AD Skopje, Skopje, North Macedonia nina.mojsovakjoseva@sparkasse.mk

Nina has a professional experience of 18 years, out of which 8 years in the pharmaceutical industry and 10 years in the banking industry; she currently works as Deputy Director of Finance Department in SPARKASSE BANK MAKEDONIJA AD SKOPJE, member of the Steiermarkische - Sparkasse Group. She is also founder and member of the Board of directors of the Association for regional development BALKAN

ECONOMIC FORUM. She holds a PhD degree in finance and economics from the

Cracow University of Economics in Poland, with the PhD thesis entitled: Financial stability and access to bank credit: evidence from the EU members of the SEE region,
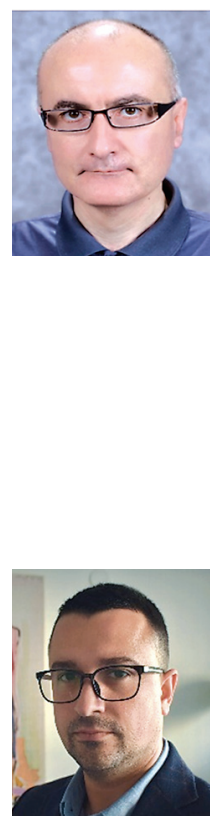
with a reference to the Republic of Macedonia.

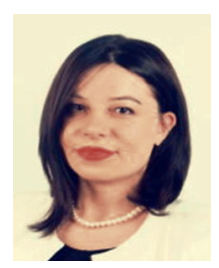

